that encode three distinct sets of proteins (systems I, II and III), each of which are homologous to signaling components responsible for bacterial chemotaxis. Only system II is essential and sufficient for chemotaxis. To gain an insight into cellular functions of the other two systems, we are examining subcellular localization of their components by using GFP-fusion constructs. System II components (CheA2 and CheY3) localize to the flagellated pole constitutively, whereas System I components (CheA1 and CheY2) also localize to the same pole, but only under anaerobic (or microaerobic) conditions. Here we observed that two other system I components, the transmembrane transducer protein Mlp13 and the adaptor protein CheW, localize at the pole only under anaerobic conditions, suggesting that the anaerobic/aerobic of control is exerted a the level of the assembly/disassembly of the MLP-CheW-CheA ternary complex. We constructed and characterized a series of deletions of CheA1 and found that P1[2] domains of CheA1 is sufficient for polar localization under anaerobic conditions. The assembly of the System I components under anaerobic condition could be involved in response to specific signals in anaerobic environments such as host intestine.

\section{P-248 プロトンポンプヘの機能転換をめざしたハロロドプシンの変異導} 入

Trial to convert halorhodopsin into a proton-pump

Keisuke Nakashima (1), Mikihiro Shibata (1), (2), Makoto Demura (3) and Hideki Kandori (1). (1: Department of Frontier Materials., Nagoya Institute of Technology; 2: School of Mathematics and Physics, College of Science and Engineering., Kanazawa University; 3 . Division of Molecular Life Sciences, Faculty of Advanced Life Science., Hokkaido University)

Bacteriorhodopsin (BR) and Halorhodopsin (HR) are light-driven proton and chloride-ion pumps, respectively. We previously converted BR into a chloride-ion pump by a single amino acid replacement (D85T) [1]. In the BR mutant, the Schiff base counterion (Asp85) was replaced to the corresponding amino acid (Thr) in HR. This finding implied that BR and HR share a common transport mechanism, and the ionic specificity is determined by the Schiff base region. However, it has been shown that the T-to-D mutant (such as T126D in pharaonis $\mathrm{HR}$ ) does not convert HR into a proton pump, suggesting that the ion-pumping mechanism is not so simple. Proton pump may be more difficult to be desioned, where the $\mathrm{pKa}$ of the proton donor and acceptor has to be considerably changed in the water-containing hydrogen-bonding network [2]

In BR, Asp96 and Glu204 constitute proton pathway, whose corresponding residues in $p \mathrm{HR}$ are Ala137 and Thr244, respectively. BR and HR possess highly conserved residues near the retinal Schiff base, such as Ala53 in BR and Ser78 in $p$ HR. Gly220 in BR and Ala260 in $p$ HR are also characteristic amino acids. In this study, we try to convert $p \mathrm{HR}$ into a proton pump based on the above mutations. In the poster, we will present various properties of these mutant proteins together with their proton-pump activities.

[1] Sasaki et al. Science 269, 73-75 (1995).

[2] Kandori Biochim. Biophys. Acta 1460, 177-191 (2000); 1658, $72-79$ (2004).

\section{P-249 PYP の N 末端領域における構造変化についての理論研究}

A theoretical study on the structural change of the $\mathrm{N}$-terminal domain of PYP

Motoshi Kamiya (1), Shinji Saito (2), Iwao Ohmine(1). (1: Chemistry Department, Faculty of Science, Nagoya Univ.; 2: Institute for Molecular Science)

Photoactive yellow protein (PYP) from Halorhodospira halophila is believed to be the photosensor for the negative phototaxis. PYP has a $p$-coumaric acid as the chromophore. The photocycle of PYP is initiated by the photoisomerization of the chromophore in the $\mathrm{pG}$ state. After the isomerization, the protonation of the chromophore and the deprotonation of Glu46 take place. This chromophore protonated state is called $\mathrm{pB}^{\prime}$. After the alteration in the protonation state of the chromophore and Glu46, the N-terminal domain undergoes structural changes, which may involve the unfolding of the $\mathrm{N}$-terminal domain. As a consequence of these structural changes, the $\mathrm{pB}$ state, which is believed to be the active structure for the signal transduction, appears.

Recently, Hoshihara et al. demonstrated that the decrease in the diffusion coefficient is coupled with the formation of pB'.(Biophys. J. 94, 2187) Since the decrease in the diffusion coefficient is closely related with the disappearance of the helices in the N-terminal region, they concluded that the unfolding of the $\mathrm{N}$-terminal region and the formation of $\mathrm{pBp}$ (protonation of the chromophore) take place simultaneously. Their result is very interesting and attractive, although it is different from the conventional idea. We thus calculated the self diffusion coefficient $\left(D_{s}\right)$ and the radius of gyration $\left(R_{g}\right)$ of PYP structures. We will discuss about the structure of $\mathrm{pB}^{\prime}$ and $\mathrm{pB}$ on the basis of $D_{s}, R_{g}$, and the free energy.

\section{P-250 全反射赤外分光法によるファラオニスフォボロドプシンのプロト} ン放出機構の研究

Early proton release from pharaonis phoborhodopsin studied by ATR-FTIR spectroscopy

Yuya Kitade (1), Yuji Furutani (1), Naoki Kamo (2) and Hideki Kandori (1).(1: Department of Frontier Materials, Nagoya Institute of Technology; 2: Graduate School of Pharmaceutical Sciences, Hokkaido University)

pharaonis phoborhodopsin ( $p \mathrm{pR}$, also called pharaonis sensory rhodopsin II; $p$ SRII) is a photoreceptor protein for negative phototaxis in Natronomonas pharaonis. In the absence of transducer protein, $p \mathrm{HtrII}, p \mathrm{pR}$ can pump protons across the membrane ilke bacteriorhodopsin (BR), the best-studied proton pomp. Previously, early proton release from the extracellular side upon formation of the $\mathrm{M}$ state of $p \mathrm{pR}$ was observed in the presence of chloride at acidic $\mathrm{pH}$, but not in their absence at any $\mathrm{pH}$ [1]. No such proton release for the mutant at Asp193 (Glu204 in BR) strongly suggested that the proton was released around this residue. In the case of BR, a protonated water cluster near Glu194 and Glu204 was identified as a proton releasing group by time-resolved FTIR spectroscopy [2, 3]. In this study, we applied attenuated total reflection (ATR) FTIR technique to investigate effect of chloride on the structure of $p \mathrm{pR}$ and the $\mathrm{M}$ intermediate. We found that Asp193 is protonated in the presence of chloride ions, while it deprotonates upon formation of the $M$ intermediate. Double difference of the $M$ minus $p \mathrm{pR}$ spectra with/without chloride coincides with the difference spectrum of chloride binding to $p \mathrm{pR}$, indicating that the $\mathrm{M}$ formation accompanies proton and chloride releases from the Asp193 region. Difference in the proton releasing mechanism between $p \mathrm{pR}$ and $\mathrm{BR}$ will be discussed.

\section{References}

[1] Iwamoto et al. Biochemistry 43, 3195 (2004).

[2] Rammelsberg et al. Biochemistry 37, 5001 (1998).

[3] Lorenz-Fonfria et al. Biochemistry 47, 4071 (2008).

\section{P-251アナベナセンサリーロドプシンとトランスデューサータンパク質 との相互作用の全反射赤外分光法による研究}

Protein-protein interaction between Anabaena sensory rhodopsin and $14 \mathrm{kD}$ soluble protein studied by ATR-FTIR spectroscopy

Yuji Furutani(1), Aya Nakatsuma(1), Akira Kawanabe(1), Kwang-Hwan Jung(2), Hideki Kandori(1)(1: Department of Frontier Materials, Nagoya Institute of Technology; 2: Department of Life Science and Interdisciplinary Program of Integrated Biotechnology, Sogang University)

Anabaena Sensory Rhodopsin (ASR) is an archaeal-type rhodopsin found in cyanobacteria. The gene encoding ASR forms a single operon with a $14 \mathrm{kDa}$ soluble protein, suggesting that ASR might function as a photoreceptor coupled with the soluble transducer. We previously revealed that ASR exhibits a $100 \%$ photochromic reaction between the all-trans and 13-cis chromophores [1]. We also reported the early structural changes of the all-trans and 13-cis forms of ASR $[2,3]$. The X-ray crystal structures of ASR and the $14 \mathrm{kD}$ protein were reported, where the $14 \mathrm{kDa}$ protein forms homo-tetramer. The previous isothermal titration calorimetry (ITC) measurement determined the dissociation constant between ASR and the tetrameric $14 \mathrm{kDa}$ protein to be $17 \mu \mathrm{M}$. However, little has been known about the molecular mechanism of the protein-protein interaction between them. Here we study the structural changes upon interaction between ASR and the $14 \mathrm{kDa}$ protein by use of Attenuated total reflection (ATR)-FTIR spectroscopy. ATR technique allows measurement of infrared spectra of samples soaked in desired buffer solution. In the meeting, we will show the effect of the $14 \mathrm{kDa}$ transducer protein on the photochromic reaction of ASR and discuss the signal transduction mechanism between them.

[1] Kawanabe et al. (2007) J. Am. Chem. Soc. 129, 8644.

[2] Furutani et al. (2005) Biochemistry 44, 12287.

[3] Kawanabe et al. (2006) Biochemistry 45, 4362.

\section{P-252 Rhodobacter capsulatus 由来 PYP の複合体状態における分光学的 特長}

Spectral characterization of the complex form of the photoactive yellow protein of Rhodobacter caplsulatus

Yoichi Yamazaki,Hironari Kamikubo and Mikio Kataoka(Graduate Schoolof Materials Science, Nara Institute of Science and Technology)

Photoactive yellow protein (PYP) is a blue light photo-receptor firstly obtained from purple sulfur photosynthetic bacteria, Halorhodospira halophila (Hh). PYP absorbs blue light by use of a covalently attached chromophore, p-coumaric acid. PYP-homologous proteins classified three types, the first group is represented by Hh-PYP which has clear single absorbance maximum around $440 \mathrm{~nm}$, and the second group is represented by PYP obtained from purple non-sulfur bacterium such as Rhodobacter capsulatus (Rc) which shows two absorbance peaks at around 370 and $440 \mathrm{~nm}$. In the rest group, PYP is a part of multi domain proteins as a sensor domain.

The Re-PYP absorbs UV light and binds with its associate protein. This complex form is suggested to be an active state in the signal transduction process. To characterize this protein-protein complex form, we determined its spectral features and dissociation constant. UV light illumination to the Rc-PYP causes trans-cis isomerization on the chromophore. The cis-form chromophore is in equilibrium of protonation and deprotonation states with a pKa 6.4. In the complex form, the deprtonated cis-form chromophore showed about $20 \mathrm{~nm}$ red-shifted absorption maximum. In acidic condition, complex form also changes its chromophore protonation state with a pKa about 6 . Thus chromophore protonation state is not influence in binding capability; actually it showed same $\mathrm{Kd}$ value for binding in acidic condition with neutral condition.

1P-253 ロドプシンのカーボンナノチューブへの内包

Encapsulation of a proton-pumping rhodopsin into carbon nanotubes

Takayoshi Kawashima (1), Kazuhiro Yanagi (2), Yuii Furutani (1). Hiromichi Kataura (2), Hideki Kandori (1). (1: Department of Frontier Materials, Nagoya Institute of Technology; 2. Nanotechnology Research Institute (NRI). National Institute of Advanced Industrial Science and Technology (AIST)

Encapsulation of small molecules into carbon nanotubes (CNT) has been extensively studied in chemistry and material sciences, because molecular 